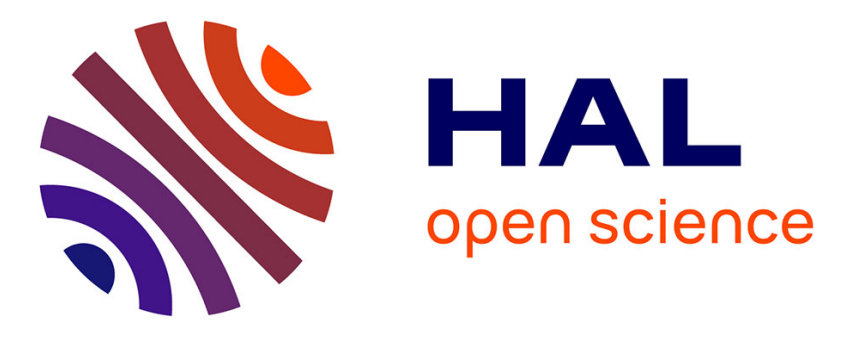

\title{
Zinc Oxide Optical Ceramic Codoped with Er3+ and $\mathrm{Yb3}+$ Ions
}

Elena Gorohova, Ivan Venevtsev, Sergey Eron'Ko, Liza Basyrova, Irina

Alekseeva, Aleksander Khubetsov, Olga Dymshits, Aleksandr Zhilin, Pavel Loiko

\section{To cite this version:}

Elena Gorohova, Ivan Venevtsev, Sergey Eron'Ko, Liza Basyrova, Irina Alekseeva, et al.. Zinc Oxide Optical Ceramic Codoped with Er3+ and Yb3+ Ions. 2021 Conference on Lasers and Electro-Optics Europe \& European Quantum Electronics Conference (CLEO/Europe-EQEC), Jun 2021, Munich, Germany. pp.1-1, 10.1109/CLEO/Europe-EQEC52157.2021.9542549 . hal-03368738

\section{HAL Id: hal-03368738 https://hal.science/hal-03368738}

Submitted on 7 Oct 2021

HAL is a multi-disciplinary open access archive for the deposit and dissemination of scientific research documents, whether they are published or not. The documents may come from teaching and research institutions in France or abroad, or from public or private research centers.
L'archive ouverte pluridisciplinaire HAL, est destinée au dépôt et à la diffusion de documents scientifiques de niveau recherche, publiés ou non, émanant des établissements d'enseignement et de recherche français ou étrangers, des laboratoires publics ou privés. 


\title{
Zinc Oxide Optical Ceramic Codoped with $\mathrm{Er}^{3+}$ and $\mathrm{Yb}^{3+}$ Ions
}

\author{
Elena Gorohova ${ }^{1}$, Ivan Venevtsev², Sergey Eron'ko', Liza Basyrova, ${ }^{3, *}$, Irina Alekseeva1, Aleksander \\ Khubetsov $^{1}$, Olga Dymshits ${ }^{1}$, Aleksandr Zhilin ${ }^{1}$, and Pavel Loiko ${ }^{3}$ \\ 1. S.I. Vavilov State Optical Institute, 36 Babushkina St., 192171 St. Petersburg, Russia \\ 2. Peter the Great St. Petersburg Polytechnic University, 29 Polytechnic St.., 195251, St. Petersburg, Russia \\ 3. Centre de Recherche sur les Ions, les Matériaux et la Photonique (CIMAP), UMR 6252 CEA-CNRS-ENSICAEN, Université de Caen \\ Normandie, 6 Boulevard du Maréchal Juin, 14050 Caen Cedex 4, France. *E-mail: liza.basyrova@ensicaen.fr
}

Zinc oxide $(\mathrm{ZnO})$ is a well-known wide-bandgap semiconductor possessing a hexagonal wurtzite-type structure. In the past years, $\mathrm{ZnO}$ nanostructures of various shapes attracted a lot of attention for applications in UV emitters, scintillators, phosphors, etc. [1]. The absorption and emission properties of $\mathrm{ZnO}$-based materials are related to defect states and can be further adjusted by doping with rare-earth ions $\mathrm{RE}^{3+}$ due to efficient $\mathrm{ZnO} \leftrightarrow \mathrm{RE}^{3}+$ energy transfer. In the present work, we report on the fabrication, microstructure and spectroscopic properties of $\mathrm{ZnO}$ optical ceramics containing erbium $\left(\mathrm{Er}^{3+}\right)$ and ytterbium $\left(\mathrm{Yb}^{3+}\right)$ ions.

$\mathrm{ZnO}$ optical ceramic codoped with $0.6 \mathrm{wt} \% \mathrm{Er}$ and $0.8 \mathrm{wt} \% \mathrm{Yb}$ was prepared by uniaxial hot pressing of $\mathrm{ZnO}$, $\mathrm{Er}_{2} \mathrm{O}_{3}$ and $\mathrm{Yb}_{2} \mathrm{O}_{3}$ commercial powders at $1180{ }^{\circ} \mathrm{C}$ in vacuum [2]. The ceramic disk ( $\Phi 25 \mathrm{~mm}$, thickness: $\left.0.5 \mathrm{~mm}\right)$ had grey coloration, Fig. 1(a). The structure of ceramics (hexagonal, sp. gr. $P 6_{3} m c$, unit-cell parameters: $a=3.251$ $\AA, c=5.202 \AA$ ) was confirmed by XRD, Fig. 1(b). The XRD pattern also revealed the crystallization of $\operatorname{Er}_{2} \mathrm{O}_{3}$ and $\mathrm{Yb}_{2} \mathrm{O}_{3}$ phases with a cubuc bixbyite-type structure (sp. gr. Ia3 ${ }^{-}, a=10.545 \AA$ and $10.441 \AA$, respectively), inset in Fig. 2(a). The average size of $\mathrm{RE}_{2} \mathrm{O}_{3}$ crystals was about $75 \mathrm{~nm}$. According to the EDX analysis, Fig. 2(c-e), apart from the stoichiometric $\mathrm{RE}_{2} \mathrm{O}_{3}$ phases, the $\mathrm{Er}^{3+}$ and $\mathrm{Yb}^{3+}$ ions are also localized on the surfaces of $\mathrm{ZnO}$ grains.

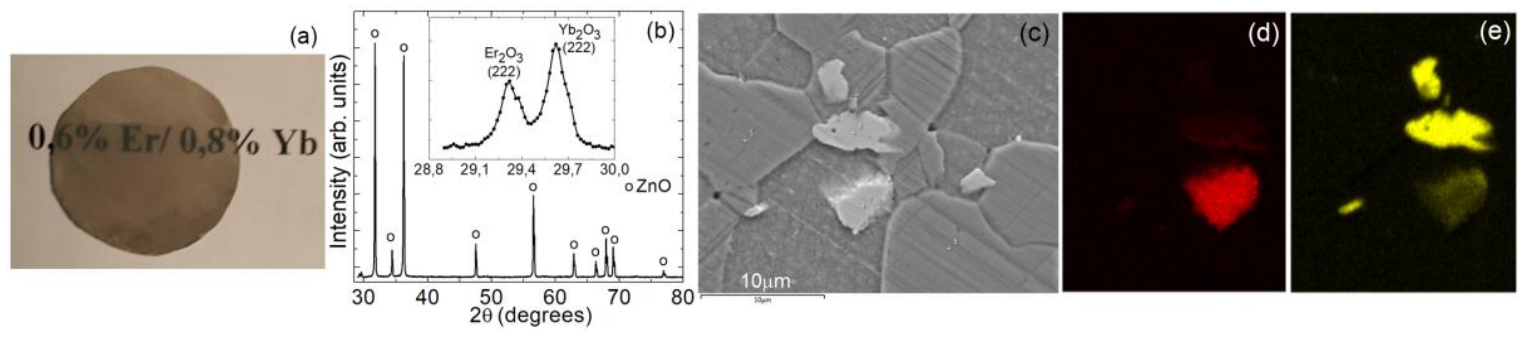

Fig. $1 \mathrm{Er}, \mathrm{Yb}: \mathrm{ZnO}$ optical ceramic: (a) photograph of the polished ceramic disk; (b) XRD pattern, inset - a close look on the main diffraction peaks of $\mathrm{Er}_{2} \mathrm{O}_{3}$ and $\mathrm{Yb}_{2} \mathrm{O}_{3}$; (c) SEM image of the polished and etched surface of the ceramic; (d,e) EDX element mapping of (d) $\operatorname{Er}(\mathrm{M} \alpha)$ and $(\mathrm{e}) \mathrm{Yb}(\mathrm{M} \alpha)$.
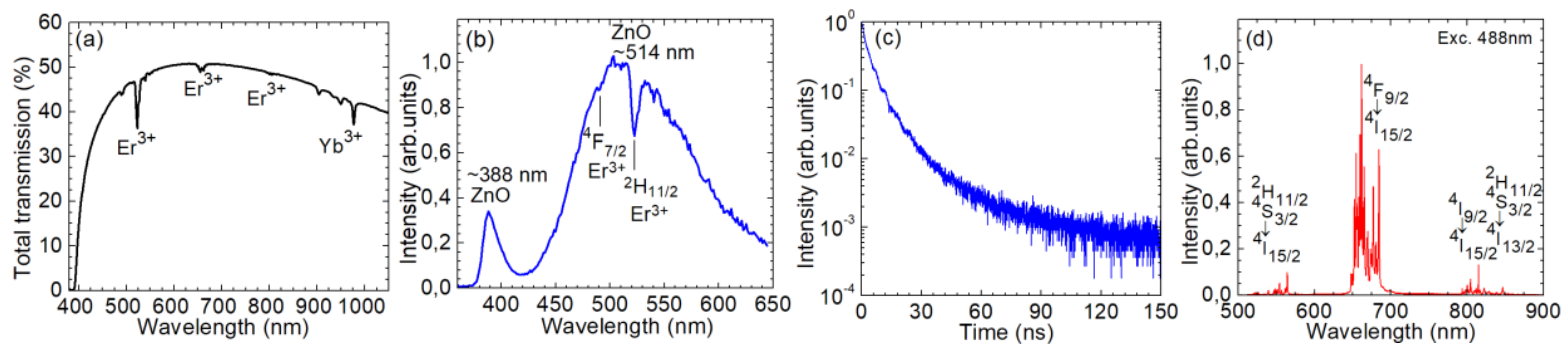

Fig. 2 Spectroscopy of Er,Yb:ZnO optical ceramic: (a) total transmission spectrum (thickness: 0.5 mm); (b) X-ray luminescence spectrum, vertical lines: deeps due to the $\mathrm{Er}^{3+}$ absorption; (c) decay curve of X-ray luminescence; (d) photoluminescence spectrum, $\lambda_{\mathrm{exc}}=488 \mathrm{~nm}$.

The maximum total transmittance of the ceramic disk is $50.9 \%$ at $\sim 0.6 \mu \mathrm{m}$, Fig. 2(a). The absorption bands are due to $\mathrm{Er}^{3+}$ and $\mathrm{Yb}^{3+}$ ions in the corresponding $\mathrm{RE}_{2} \mathrm{O}_{3}$ phases. The X-ray luminescence spectrum, Fig. 2(b), has two intense emission bands both being characteristic of $\mathrm{ZnO}$. The band at $\sim 388 \mathrm{~nm}$ is due to the near-band-edge (NBE) transitions. The second broad band centered at $\sim 514 \mathrm{~nm}$ represents the defect emissions. The spectral "holes" coincide with the absorption of $\mathrm{Er}^{3+}$ ions. The average X-ray luminescence decay time in the "fast" time domain of 0-50 ns is 6-8 ns, Fig. 2(c). Note that it is about $65 \mathrm{~ns}$ for undoped $\mathrm{ZnO}$ ceramic [2], indicating the $\mathrm{ZnO} \rightarrow \mathrm{RE}^{3}+$ energy transfer. Under optical excitation at $488 \mathrm{~nm}$, the photoluminescence spectrum contains emission bands assigned to $\mathrm{Er}^{3+}$ ions in $\mathrm{RE}_{2} \mathrm{O}_{3}$ crystals, Fig. 2(d). The work on determining the most promising $\mathrm{Er}^{3+} / \mathrm{Yb}^{3+}$ codoping ratio is in progress. The developed $\mathrm{Er}^{3+}, \mathrm{Yb}^{3+}$-codoped $\mathrm{ZnO}$ optical ceramic demonstrates high radiation stability. It is promising for optoelectronic applications.

\section{References}

[1] A. B. Djurišić, Y. H. Leung, K. H. Tam, L. Ding, W. K. Ge, H. Y. Chen, and S. Gwo, "Green, yellow, and orange defect emission from ZnO nanostructures: Influence of excitation wavelength,” Appl. Phys. Lett. 88(10), 103107 (2006).

[2] E. Gorohova, E. Oreschenko, L. Basyrova, I. Venevtsev, S. Eron'ko, I. Alekseeva, A. Khubetsov, O. Dymshits, P. Loiko, A. Zhilin, and P. Rodnyi, "Structure and spectral-luminescent properties of $\mathrm{Er}^{3+}: \mathrm{ZnO}$ optical ceramics," J. Phys. Conf. Ser. 1965, 012041 (2020). 